\section{COMBUSTION PERFORMANCE OF SYNGAS FROM PALM KERNEL SHELL IN A GAS BURNER}

\author{
Asmadib Yusoff @ Adnana, Muhammad Roslan Rahima, \\ Mohammad Nazri Mohd Jaafara,b*, Norazila Othmana, Mohd \\ Shuisma Mohd Ismaila, Kamal Arifina, Mohd Faizal Hasana
}

aschool of Mechanical Engineering, Faculty of Engineering, Universiti Teknologi Malaysia, 81310 UTM Johor Bahru, Johor, Malaysia

bInstitute for Vehicle Systems and Engineering, Universiti Teknologi Malaysia, 81310 UTM Johor Bahru, Johor, Malaysia
Article history

Received

11 June 2019

Received in revised form

12 September 2019

Accepted

13 September 2019

Published online

24 October 2019

*Corresponding author nazri@mail.fkm.utm.my

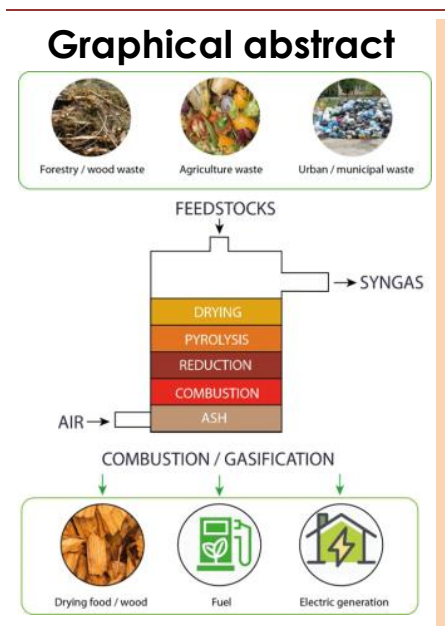

\begin{abstract}
Insufficient and various environmental issues of fossil fuels as the current world dominated energy is now becoming a serious global issue. The rapidly increasing demand for alternative energy sources has contributed to the steady growth of renewable energy. Owing to the fact of the abundant presence of palm kernel shell (PKS) as one of palm biomass wastes in South East Asia region, this paper investigates syngas produced from gasified PKS. The investigation is regarding its composition and combustion performance in a gas burner system. It covers emissions analysis, temperature profile and flame length. The produced syngas from downdraft gasifier was burned in the combustion chamber in air-rich and fuel-rich combustion conditions. From the experiment, the results showed that the oxidation zone temperature of above $750^{\circ} \mathrm{C}$ for the downdraft gasifier is suitable for producing syngas. Produced syngas can be classified as pure-carbon monoxide (CO) syngas due to $94.9 \%$ CO content with no hydrogen $\left(\mathrm{H}_{2}\right)$ content and low heating value (LHV) of $10.7 \mathrm{MJ} / \mathrm{kg}$. The wall temperature profiles for burnt syngas produced via downdraft gasification was higher with longer pattern at fuel-rich condition, which signified higher energy of syngas produced from downdraft gasifier compared to fluidised bed gasifier. The associated flame length was also longer at fuel-rich condition. Produced emission of $56 \mathrm{ppm} \mathrm{NOx}, 37 \mathrm{ppm} \mathrm{CO}$ and $1 \mathrm{ppm} \mathrm{SO}$ can still be considered as acceptable to human. It can be concluded that syngas produced from PKS shown a high potential to serve as an alternative source of energy due to its high energy content.
\end{abstract}

Keywords: Syngas, Palm Kernel Shell (PKS), gasification, combustion, emission

\begin{abstract}
Abstrak
Kekurangan bahan api fosil serta pelbagai isu alam sekitar berpunca darinya kerana ia mendominasi tenaga dunia masakini menjadi isu global yang serius. Permintaan sumber tenaga alternatif yang meningkat secara mendadak telah menyumbang kepada pertumbuhan mantap tenaga boleh diperbaharui. Oleh kerana fakta menunjukkan terdapat lambakan tempurung isirong kelapa sawit (PKS) yang merupakan salah satu sisa biojisim sawit di rantau Asia Tenggara, artikel ini memaparkan hasil kajian syngas yang dihasilkan daripada penggasan PKS. la mengkaji komposisi singas dan prestasi pembakarannya dalam sistem pembakar gas. Kajian meliputi analisis emisi, profil suhu dan panjang nyalaan. Singas yang dihasilkan dari penggas tetap aliran tiup bawah dibakar dalam kebuk pembakaran pada keadaan pembakaran yang kaya dengan udara dan yang kaya dengan bahan api. Dari ujikaji, keputusan menunjukkan bahawa suhu zon pengoksidaan melebihi $750^{\circ} \mathrm{C}$ untuk penggas tetap aliran tiup bawah sesuai untuk menghasilkan singas. Singas yang dihasilkan boleh dikategorikan sebagai karbon monoksida asli (CO) kerana $94.9 \%$ daripada kandungannya adalah dalam bentuk $\mathrm{CO}$, tanpa kandungan hidrogen $\left(\mathrm{H}_{2}\right)$. Nilai pemanasan rendah (LHV) adalah $10.7 \mathrm{MJ} / \mathrm{kg}$. Profil suhu dinding kebuk untuk pembakaran singas yang dihasilkan melalui penggas tetap aliran tiup bawah adalah lebih tinggi dengan corak yang
\end{abstract}


lebih lama pada keadaan kaya bahan api, yang menandakan tenaga yang lebih tinggi daripada singas yang dihasilkan dari penggas tetap aliran tiup bawah berbanding menurunkan tekanan dari penggas lapisan terbendalir. Nyalaan adalah lebih panjang pada keadaan kaya bahan api. Kepekatan emisi $\mathrm{NO}$ x pada nilai 56 ppm, CO 37 ppm dan SO 21 ppm masih dianggap sebagai boleh diterima manusia. Dapat disimpulkan bahawa singas yang dihasilkan daripada PKS menunjukkan potensi tinggi untuk digunakan sebagai sumber tenaga alternatif kerana kandungan tenaganya yang tinggi.

Kata kunci: Singas, Tempurung Isirong Kelapa Sawit (PKS), Penggasan, Pembakaran, Emisi

2019 Penerbit UTM Press. All rights reserved

\subsection{INTRODUCTION}

Biomass is a renewable, sustainable and alternative source of energy with a huge potential due to low sulphur and nitrogen content as compared to conventional fossil-fuel resources. Fossil fuel resource is the world dominated energy source. However, it negatively impacts the environment [1-4]. An economy related to biomass energy creates singnifiant development since last decade. Various types of biomass feedstock, wastes, products and technologies are ready to be utilised and optimised. At the same time, to produce a clean and environmentally friendly fuel with lower SOx and $\mathrm{NOx}$ emissions. Besides, carbon dioxide $\left(\mathrm{CO}_{2}\right)$ foot-print is going to fulfill global demands and vast environmental concerns. Furthermore, common environmental issues due to the excessively produced emissions from the fossil fuels sources have tempted the world to reduce carbon emissions by $80 \%$ and shift towards utilising a variety of renewable energy resources which are less detrimental to the environment such as solar, wind, biomass etc in a sustainable manner [2].

Malaysian oil palm industry is one of the largest contributors of lignocellulosic based biomass, which comprises more than $90 \%$ of total domestic biomass, as derived from 5.4 million hectare areas of oil palms. The total oil palm biomass availability is forecasted to increase further, owing to current initiatives on fasttracking replanting activity, improving oil extraction rate and growing mill capacity. As an example of palm oil biomass waste, PKS is carbonaceous solid materials which are typically leftovers from palm oil mill processing that contains high volume percentage of carbon element and it can be converted to heat energy source by thermal reaction [6]. PKS has a quite significant content of volatile matter and a moderate proportion of fixed carbon. However, it has a low content of fuel moisture and ash, thus resulting in higher high heating value (HHV) [6]. The proximate analysis can experimentally determine fixed carbon, moisture content, volatile matter and ash percentage in the PKS. Through ultimate analysis, apart from associated mineral, the main chemical elements in PKS are carbon $(\mathrm{C})$, oxygen $(\mathrm{O})$, hydrogen $(\mathrm{H})$, nitrogen (N) and sulphur (S) are determined and balanced accurately by chemical analysis and expressed on a moisture free basis, apart from the fuel calorific value
(CV) determination.

Biomass waste possesses a tremendous prospect to be a very promising alternative source of raw feedstock for generating synthesis gas (or syngas), owing to the fact of its abundance, $\mathrm{CO}_{2}$ neutrality and sustainability [8]. The utilisation of biomass feedstock is preferred over other alternative resources due to its convertibility into both liquid and gas fuel by both biological and thermochemical techniques. Technologies for converting biomass into the fuel can be categorised into direct combustion, biochemical, agrochemical and thermochemical processes [9]. Thermochemical conversion processes can be further classified into gasification, pyrolysis, supercritical fluid extraction and direct liquefaction. Gasification is one of the most efficient thermochemical conversion technologies to produce gaseous fuel with high calorific value (CV) from biomass feedstock as corresponded in high heating value (HHV) [10-12]. To date, notable progress has been accomplished in producing syngas from biomass feedstock [9, 13, 14]. Biomass gasification normally involves gasification agents such as oxygen, air, steam or combinations of few air-steam and steam-oxygen. Syngas that was produced at low temperature (below $1000^{\circ} \mathrm{C}$ ) comprises mainly of hydrogen $\left(\mathrm{H}_{2}\right)$, carbon monoxide (CO), carbon dioxide $\left(\mathrm{CO}_{2}\right)$, nitrogen $\left(\mathrm{N}_{2}\right)$, water vapor, methane $\left(\mathrm{CH}_{4}\right)$, other hydrocarbons, benzene, tolvene and tars [15,16]. Approximately $50 \%$ of the energy in the syngas is contributed by $\mathrm{H}_{2}$ and $\mathrm{CO}$ element, whereas the remaining energy is contained in $\mathrm{CH}_{4}$ and aromatic hydrocarbons. Typical gasification reactor operation is drying, pyrolysis / devolatilisation, reduction and combustion [15-20].

Downdraft gasifier reactor operates with the primary gasification agent supplied at or above the oxidation zone. Typically, downdraft gasifier capacity ranges between $10 \mathrm{~kW}$ - $1 \mathrm{MW}$ which makes it more suitable for small-scale applications. As downdraft is also suitable to produce highly volatile syngas, the supplied biomass feedstock used should be relatively dry (up to $30 \%$ moisture approximately) and contain low ash (less than 1\% in weight). Highly volatile matters are highly prone to vaporise, hence can be combusted easily. The presence of highly reactive oxidised of carbon dioxide with the oxygen in the air inside the oxidation zone is beneficial to produce hot gas for combustion purpose. The high temperature at 
the outlet of gasifier is vital to produce low tar content of less than $0.5 \mathrm{~g} / \mathrm{m}^{3}$ whereas high local temperatures in the oxidation zone can potentially melt some ash constituents. Overall, gasification using downdraft is a very attractive option due to its simple operation, easy fabrication and low tar content formed in the produced syngas [21-23].

Bubbling fluidised bed (BFB) is a vessel with a grate at the bottom through which air or steam is introduced as gasifying agents and utilises fine inert particles of sand or alumina as bed material to prevent the ash from softening and forming defluidisation phenomena. Biomass feedstock is pyrolysed in the high temperature bed above the grate to form char with gaseous compounds. The char and gaseous compounds are decomposed upon contact with hot bed material in presence of gasification agent due to the frictional force between the particles. The gas flow to counterbalance the weight of the solids. Bubbling and channeling of gas occur through the media as characterised by discrete bubbles at relatively low velocity $(<5 \mathrm{~m} / \mathrm{s})$ [23]. The cyclonic mechanism separates the extracted ash/char particles from the produced syngas. The solid particles return to the bottom of bed and form an internal solid circulation. Strong vortex of gas-solid flow is supplied to increase fluid velocity in the reactor, thus provide a homogeneous temperature profile throughout biomass thermochemical reaction [25]. As the bed comprises mostly ash, temperature is maintained at $700-1000^{\circ} \mathrm{C}$ by varying the air/biomass ratio to prevent agglomeration. The equivalence ratio of gasifying agent to fuel ratio has effects on the $\mathrm{CO}$, $\mathrm{CO}_{2}, \mathrm{CH}_{4}, \mathrm{H}_{2}$ and $\mathrm{N}_{2}$ concentrations as well as $\mathrm{CV}$ of the produced syngas [9, 23 - 27].

Previous researchers have studied on producing syngas from various gasification methods from oil palm biomass wastes such as palm oil mill effluent (POME), empty fruit bunch (EFB), mesocarp fibers (MSF) and palm oil fronds (POF) through various gasifiers have also been researched $[17,27,28]$. Specifically on PKS, an experimental study on combusting PKS in a conical fluidised-bed combustor (FBC) has been conducted and concluded that the best combustion and emission performance are achievable when burning PKS with a mean particle size of about $5 \mathrm{~mm}$ at excess air of $40-$ $50 \%$ [29]. Under these conditions, the combustor can be operated with high combustion efficiency (99.4$99.7 \%$ ) and gaseous emissions controlled within acceptable limits with no evidence of alumina throughout experimental period [29]. Experimental study on the combustion performance of palm oil based biodiesels in an oil burner system has also been conducted by several researchers, which produced considerably low emissions, high temperature profile (nearly $800^{\circ} \mathrm{C}$ ) and long flame length (nearly $900 \mathrm{~mm}$ ) [30-32]. The produced flame is longer at higher temperature profile in fuel-rich combustion condition. As there is no similar study on syngas, hence this experimental research aims to produce syngas from PKS via downdraft gasifier respectively and study its combustion performance of the produced syngas in a gas burner in term of its temperature profile, emissions and flame length.

\subsection{METHODOLOGY}

\subsection{Material}

Biomass waste samples used in this investigation were raw PKS with an average size of $4-20 \mathrm{~mm}$ which was donated by Kyoto Oil and Grains Industries Sdn. Bhd. This factory is located at Kuantan Port, Pahang. The sample underwent the preparation stage such as cleaning, drying and sizing with a purposes to reduce the moisture content of the sample and to remove any contaminant that may affect the results. Optionally, the cleaned sample can also be placed in an oven for overnight at temperature of $45^{\circ} \mathrm{C}$.

\subsection{Proximate and Ultimate Analysis}

PKS was grinded and sieved in the size of $0.250 \mathrm{~mm}$. The $10 \mathrm{~g}$ PKS sample was tested and analysed at Chemical Engineering Laboratory, Faculty of Chemical Engineering, Universiti Teknologi Malaysia for proximate and ultimate analysis using methods as described in previous publication [33] to determine the $\mathrm{CV}$, elemental and component composition, as shown in Tables 1, 2 and 3.

Table 1 Calorific value for PKS

\begin{tabular}{cc}
\hline Calorific value & HHV $(\mathrm{MJ} / \mathrm{kg})$ \\
\hline Quantity & 22.3 \\
\hline
\end{tabular}

Table 2 Proximate analysis result for PKS

\begin{tabular}{lc}
\hline Element & (wt.\% dry basis) \\
\hline Moisture content & 8.25 \\
Volatile matter & 63.76 \\
Fixed carbon & 17.31 \\
Ash & 10.68 \\
\hline
\end{tabular}

Table 3 Ultimate analysis result for PKS

\begin{tabular}{cc}
\hline Element & (wt.\% dry basis) \\
\hline C & 34.07 \\
H & 3.35 \\
O & 48.29 \\
N & 0.86 \\
S & 0.09 \\
\hline
\end{tabular}

2.3 Gasification and Combustion Performance Test Experimental Set-Up

The set-up includes a DG-50 open top downdraft gasifier, 25kW fluidised bed gasifier, gas burner with a standard axial swirler (Brand: Baltur BT14), type-K thermocouples with a maximum temperature of $1200^{\circ} \mathrm{C}$, a $1000 \mathrm{~mm}$ length open-ended mild steel combustion chamber insulated with cast cement, a 
Midi temperature data logger, an LCA 6000 air speed indicator, a Horiba Enda 5000 gas analyzer, long high temperature rubber hose, a 1 meter long ruler and few digital cameras with tripods. The burner was positioned at the inlet of the combustion chamber. Eight thermocouples were placed on top surface along the wall of the combustion chamber at equal distance of $100 \mathrm{~mm}$. The thermocouples were connected to the data logger, which produces wall temperature readings from the generated electrical signal.

Figures 1 (a) until (c) indicate the downdraft experimental set-up, schematic and procedure for the gasification and combustion test. The gasifier was ensured to be clean and PKS feedstock was fed from the top, prior to commencing the gasification process. Subsequently, the feedstock was burnt in the downdraft reactor while fresh air flow as a gasifying agent was supplied continuously at $1.133 \mathrm{~m}^{3} / \mathrm{min}$ using a blower through air inlet that is controllable using a valve. Within the reactor, air reacted with PKS raw feedstock to produce syngas. The gasification operating temperatures varied between $100^{\circ} \mathrm{C}$ and $1000^{\circ} \mathrm{C}$. The produced syngas was routed from the outlet of the gasifier reactor to the gas burner rig via a long high temperature hose and the syngas volume was controlled by an outlet valve. Typical duration for syngas generation to commence was between 45 and 60 minutes.

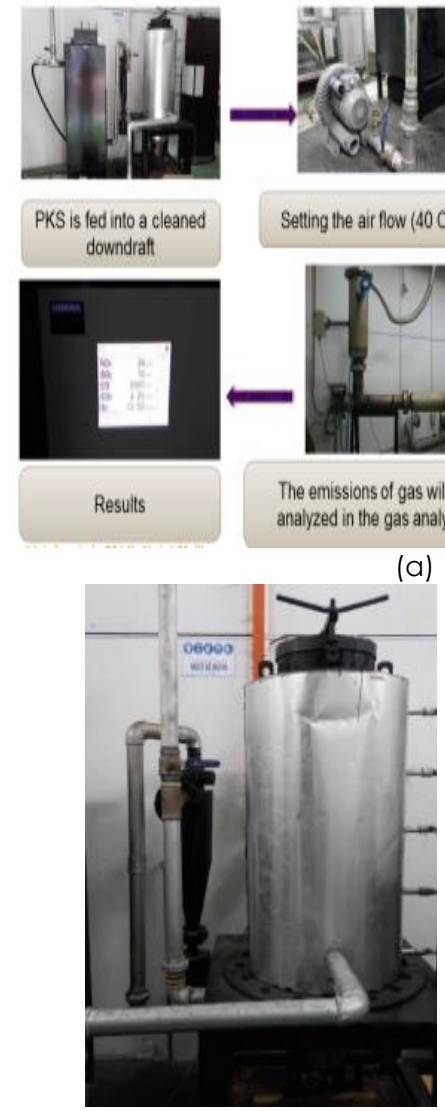

(b)

a)
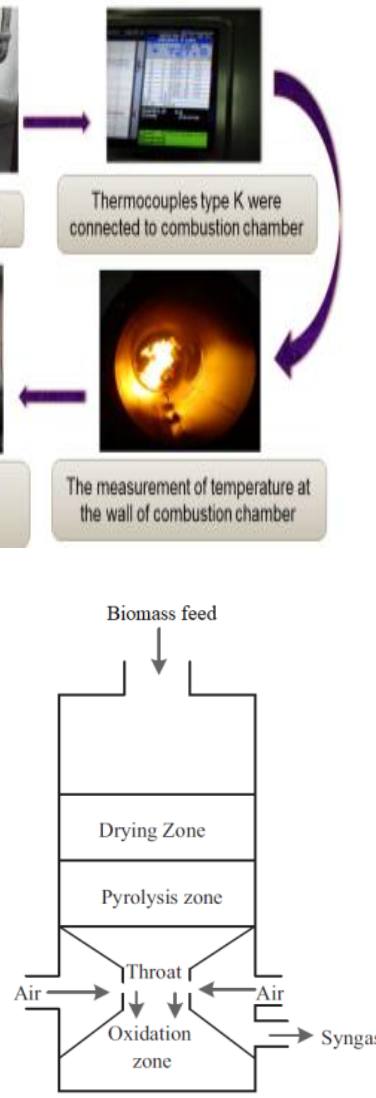

(c)
Figure 1 (a) Experiment setup for gasification via downdraft gasifier (b) Downdraft gasifier (c) Schematic of gasification in a downdraft gasifier
After 10 minutes of the first syngas produced, the combustion was initiated at the gas burner by using an external portable torch until the flame produced reached stabilisation (around 10 to 20 minutes). The wall temperatures along the combustion chamber were recorded using the data logger and exhaust emission is measured using Horiba Enda 5000 gas analyser [30-32].

For the syngas combustion test experimental set-up, the schematic is illustrated in Figures 2 (a) and (b). After the wall temperatures recording were completed, the flame length can be measured. A long ruler was hooked up perpendicular to the burner for proper measurement. Fuel-rich and air-rich combustion conditions can be simulated by varying the air flow to the burner.

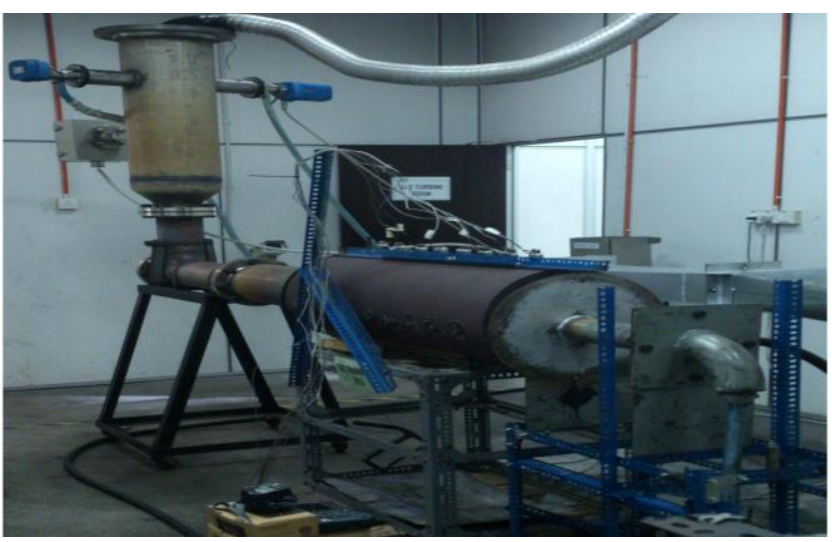

(a)

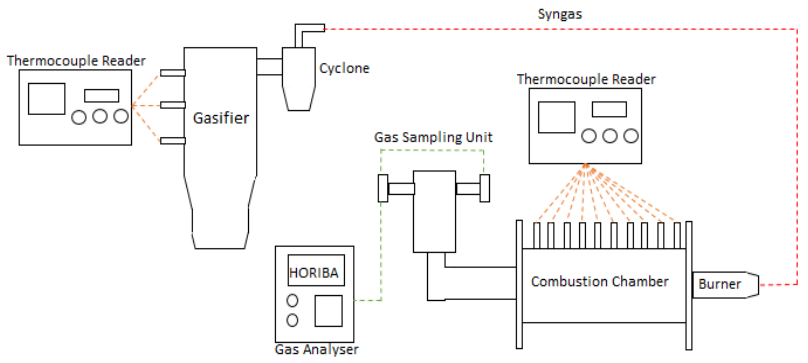

(b)

Figure 2 (a) Combustion chamber experimental set-up (b) Schematics diagram of the experimental rig set up

\subsection{RESULTS AND DISCUSSIONS}

\subsection{Syngas Composition}

The produced syngas composition is summarised in Table 4. From the experiment, the oxidation zone temperature above $750^{\circ} \mathrm{C}$ for the downdraft gasifier is suitable for producing syngas. The obtained syngas can be categorised as pure-CO syngas as it is composed of $94.9 \% \mathrm{CO}$ with no $\mathrm{H}_{2}$ content [34]. Therefore, the syngas LHV value was much lower than typical $\mathrm{H}_{2}$ rich gas fuel. The LHV of the syngas was determined by multiplying each element LHV with each element gas composition that is $\mathrm{H}_{2}, \mathrm{CO}$ and $\mathrm{CH}_{4}$ due to combustibility capability. Fundamentally in 
industrial application, volume fraction of $\mathrm{H}_{2}$ content in syngas fuel significantly impact the life of hot sections of gas turbines as resultant of higher flame temperature for $\mathrm{H}_{2}$-rich fuels as well as the moisture content of combustion products [35].

Table 4 Syngas composition and heating value from gasification of PKS.

\begin{tabular}{cccccc}
\hline $\begin{array}{c}\mathrm{CO} \\
\text { content }\end{array}$ & $\begin{array}{c}\mathrm{CO} \\
\text { (vol.\%) }\end{array}$ & $\begin{array}{c}\mathrm{H}_{2} \\
\text { (vol.\%) }\end{array}$ & $\begin{array}{c}\mathrm{CO}_{2} \\
\text { (vol.\%) }\end{array}$ & $\begin{array}{c}\mathrm{CH}_{4} \\
\text { (vol.\%) }\end{array}$ & $\begin{array}{c}\text { LHV } \\
\text { (MJ/kg) }\end{array}$ \\
\hline Pure & 94.9 & 0.0 & 1.8 & 2.0 & 10.7 \\
\hline
\end{tabular}

Lower heating value for $\mathrm{CO}=10.16 \mathrm{MJ} / \mathrm{kg} ; \mathrm{H}_{2}=120.1 \mathrm{MJ} / \mathrm{kg}$;

$\mathrm{CH}_{4}=49.9 \mathrm{MJ} / \mathrm{kg} ; \mathrm{CO}_{2}=0 \mathrm{MJ} / \mathrm{kg}$.

\subsection{Wall Temperature Profile}

As illustrated in Figure 3, wall temperatures for burnt syngas produced from gasification via downdraft were higher than temperatures produced from fluidised bed gasifier with longer pattern at fuel-rich condition. This means higher energy syngas was produced from downdraft gasifier due to higher carbon conversion [23]. The temperature profile begins with the increase of the wall temperature at a distance of $100 \mathrm{~mm}$ to $400 \mathrm{~mm}$ from the burner inlet. The highest wall temperature is at $\theta$ the chamber length of $600 \mathrm{~mm}$ [30-32]. It is the point where air and fuel are homogeneously combusted together to produce a higher amount of heat energy [30-32] thus indicating the size of the flame formed. The wall temperature started to drop after that point, which means that the flame is nearing its tip. The fuel to air (F/A) ratio or also termed as equivalence ratio (ER) influenced the wall temperature profile for the burnt syngas. Theoretically, by increasing the ER from less than 1.0 to greater than 1.0, the fuel-air combustion condition changes from a lean-fuel mixture to a rich-fuel mixture. As a result, the volume of air flow decreases as the fuel flow rate increases.

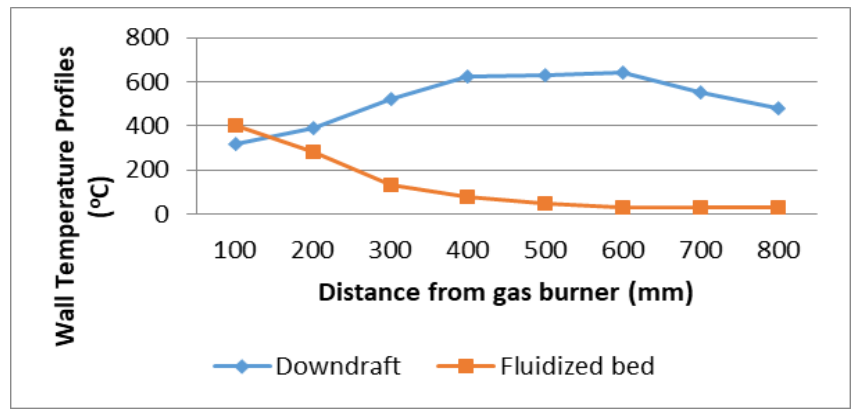

Figure 3 Wall temperatures at fuel-rich combustion condition

\subsection{Flame Length}

As illustrated in Figures 4 (a) and (b) and 5, it can be observed that the flame length for the produced syngas via downdraft was $350 \mathrm{~mm}$ to $400 \mathrm{~mm}$ in air-rich combustion condition. In comparison, in fuel-rich combustion condition in Figure 5, the flame length for produced syngas via downdraft was between 450 and $500 \mathrm{~mm}$. These results synchronised well with the wall temperatures data which is related to higher energy syngas produced from downdraft gasifier. The flame air-rich combustion seemed more straight and brighter as soot formations also decreased at this condition [3032].

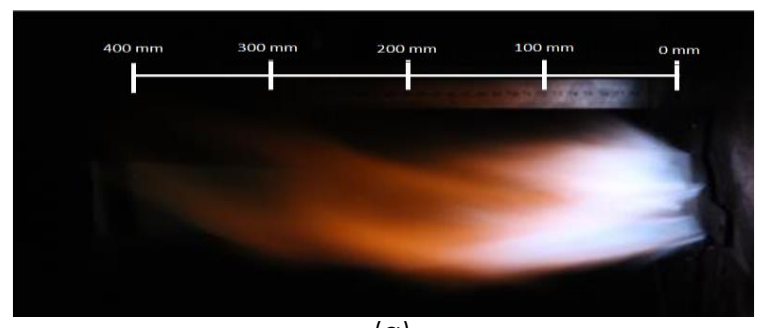

(a)

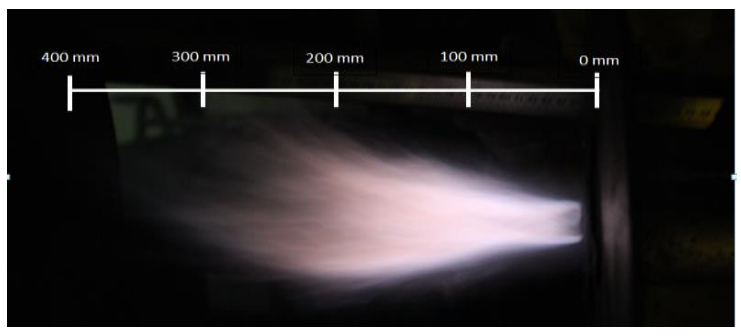

(b)

Figure 4 (a) and (b) shows a flame length in air-rich combustion

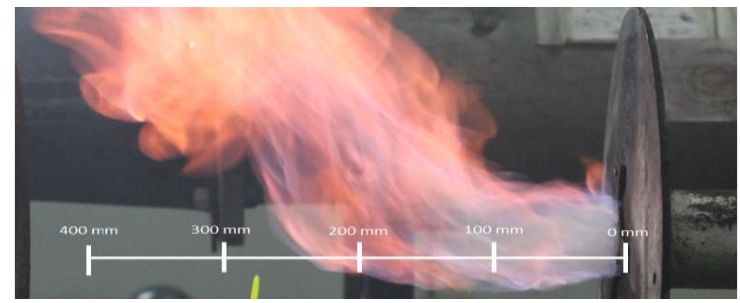

Figure 5 Flame length in a fuel-rich combustion

\subsection{Emissions}

The experimental results for the gaseous emission concentrations for $\mathrm{NO}_{2}, \mathrm{SO}_{2}$, and $\mathrm{CO}$ are recorded in Table 5. The value of $\mathrm{SO}_{2}$ remained low as the $\mathrm{CO}$ and NOx emissions increased due to PKS contained low sulphur content, as proven during the ultimate analysis. However, during the combustion of the fuel-rich condition, $\mathrm{CO}$ emissions increased to $37 \mathrm{ppm}$ with $\mathrm{NO}$ content at $56 \mathrm{ppm}$. Theoretically, $\mathrm{CO}$ emission is influenced by two main factors. The first factor is the lack of air supply in which it is affected by $\mathrm{O}_{2}$ supply during combustion while the second factor is low combustion temperature. In this experiment, the first factor was more dominant as it can be seen that the $\mathrm{O}_{2}$ percentage continued to decrease as the $\mathrm{CO}$ 
emission increased [36]. Also, notably, there was a relationship between $\mathrm{NOx}$ emissions formation and $\mathrm{CO}$ whereby $\mathrm{CO}$ emissions decreased, NOx emissions increased. Throughout the gasification and combustion performance experiment, high level of $\mathrm{CO}$ emissions was recorded due to the syngas composition was CO-pure and the produced syngas was not treated after the gasification. The $\mathrm{CO}$ and $\mathrm{NOx}$ emissions can be reduced when the combustion process produces high temperatures, short residence time and short flame retardation [36].

Table 5 Emissions produced

\begin{tabular}{cccccc}
\hline Emission & $\begin{array}{c}\mathrm{NO} \times \\
(\mathrm{ppm})\end{array}$ & $\begin{array}{c}\mathrm{SO}_{2} \\
(\mathrm{ppm})\end{array}$ & $\begin{array}{c}\mathrm{CO} \\
(\mathrm{ppm})\end{array}$ & $\begin{array}{c}\mathrm{CO}_{2} \\
(\%)\end{array}$ & $\begin{array}{c}\mathrm{O}_{2} \\
(\%)\end{array}$ \\
\hline Quantity & 56 & 1 & 37 & 5.94 & 14.91 \\
\hline
\end{tabular}

\subsection{CONCLUSION}

Syngas can be obtained from PKS as one of the common biomass wastes through gasification process using downdraft gasifier. From proximate analysis, PKS contains the high value of fixed carbon content, thus possesses high potential to produce syngas with high LHV value. However, PKS has high ash content that could result in inferior syngas production. From the experiment, the oxidation zone temperature above $750^{\circ} \mathrm{C}$ for the downdraft gasifier is suitable for producing syngas. The obtained syngas can be classified as pure-CO syngas due to $94.9 \%$ CO content with no $\mathrm{H}_{2}$ content. Thus, this syngas LHV value of 10.7 $\mathrm{MJ} / \mathrm{kg}$ can be considered lower than typical $\mathrm{H}_{2}$-rich syngas, but still among the highest as compared with other biomass. In term of combustion performance, wall temperatures profile for burnt syngas produced from gasification via downdraft was higher compared to wall temperatures produced from fluidisedbed gasifier with more extended pattern condition. This means higher energy syngas produced from downdraft gasifier due to higher carbon conversion. The associated flame length was also much longer at fuel-rich condition. As the produced syngas was not treated after the gasification and possessed high $\mathrm{CO}$ content readily, this has resulted in high $\mathrm{CO}$ gas emission. Based on results obtained from the experimental study, PKS was found to have high potential as a fuel for gasification. Subjected to syngas reconditioning, syngas derived from PKS has the potential to be used as alternative fuel for power generation, transportation fuels and chemical production.

\section{Acknowledgements}

The authors would like to thank the Research Management Center and School of Mechanical Engineering, Faculty of Engineering, Universiti Teknologi Malaysia for providing the research grants Tier 1 vote
17 H47 and Tier 2 vote16J35, space and facilities to undertake this research study.

\section{References}

[1] Samiran, Nor Afzanizam, Mohd Jaafar, Mohammad Nazri, Cheng Tung Chong, and Jo Han Ng. 2015. A Review of Palm Oil Biomass as a Feedstock for Syngas Fuel Technology. Jurnal Teknologi. 72(5): 13-18.

[2] Saidur, Rahman, E. A. Abdelaziz, Ayhan Demirbas, M. S. Hossain, and Saad Mekhilef. 201 1. A Review on Biomass as a Fuel for Boilers. Renewable and Sustainable Energy Reviews. 15(5): 2262-2289.

[3] Sansaniwal, S. K., M. A. Rosen, and S. K. Tyagi. 2017. Global Challenges in the Sustainable Development of Biomass Gasification: An Overview. Renewable and Sustainable Energy Reviews. 80: 23-43.

[4] Ani, F. N. 2000. Production of Bio-oil from Palm Oil Shell. Jurnal Kejuruteraan. 12: 105-116.

[5] Shuit, Siew Hoong, Kok Tat Tan, KEAT TEONG Lee, and A. H. Kamaruddin. 2009. Oil Palm Biomass as a Sustainable Energy Source: A Malaysian Case Study. Energy. 34(9): 1225-1235.

[6] Abdullah, N., and F. Sulaiman. 2013. The Oil Palm Wastes in Malaysia. In Biomass Now-Sustainable Growth and Use. InTech.

[7] Loh, Soh Kheang. 2017. The Potential of the Malaysian Oil Palm Biomass as a Renewable Energy Source. Energy Conversion and Management. 141: 285-298.

[8] Singh, Ram Sarup, Ashok Pandey, and Edgard Gnansounou, eds. 2016. Biofuels: Production and Future Perspectives. CRC Press.

[9] Ahmad, Anis Atikah, Norfadhila Abdullah Zawawi, Farizul Hafiz Kasim, Abrar Inayat, and Azduwin Khasri. 2016. Assessing the Gasification Performance of Biomass: A Review on Biomass Gasification Process Conditions, Optimization and Economic Evaluation. Renewable and Sustainable Energy Reviews. 53: 1333-1347.

[10] Panwar, N. L., Richa Kothari, and V. V. Tyagi. 2012. Thermo Chemical Conversion of Biomass-eco Friendly Energy Routes. Renewable and Sustainable Energy Reviews. 16(4): 1801-1816.

[11] Klass, Donal L. 2004. Biomass for Renewable Energy and Fuels. Encyclopedia of Energy. 1 (1): 193-212.

[12] Yllmaz, Sebnem, and Hasan Selim. 2013. A Review on the Methods for Biomass to Energy Conversion Systems Design. Renewable and Sustainable Energy Reviews. 25: 420-430.

[13] Demirbaş, Ayhan. 2001. Biomass Resource Facilities and Biomass Conversion Processing for Fuels and Chemicals. Energy conversion and Management. 42(11): 1357-1378.

[14] Lan, Weijuan, Guanyi Chen, Xinli Zhu, Xuetao Wang, and Bin Xu. 2015. Progress in Techniques of Biomass Conversion into Syngas. Journal of the Energy Institute. 88(2): 151-156.

[15] Asadullah, Mohammad. 2014. Barriers of Commercial Power Generation Using Biomass Gasification Gas: A Review. Renewable and Sustainable Energy Reviews. 29: 201-215.

[16] Brachi, Paola, Riccardo Chirone, Francesco Miccio, Michele Miccio, Antonio Picarelli, and Giovanna Ruoppolo. 2014. Fluidized Bed Co-gasification of Biomass and Polymeric Wastes for a Flexible End-use of the Syngas: Focus on BioMethanol. Fuel. 128: 88-98.

[17] Atnaw, Samson Mekbib, Shaharin Anwar Sulaiman, and Suzana Yusup. 2011. Downdraft Gasification of Oil-Palm Fronds. Trends in Applied Sciences Research. 6(9): 1006.

[18] Daud, Ahmad Amirul Asraf Mohd. 2014. Palm Oil Waste Gasification: the Effect of Operating Temperature for Hydrogen Production. PhD diss., UMP.

[19] Mayerhofer, M., S. Fendt, H. Spliethoff, and M. Gaderer. 2014. Fluidized Bed Gasification of Biomass-in Bed Investigation of Gas and Tar Formation. Fuel. 117: 1248-1255.

[20] Son, Young-ll, Sang Jun Yoon, Yong Ku Kim, and Jae-Goo Lee. 2011. Gasification and Power Generation 
Characteristics of Woody Biomass Utilizing a Downdraft gasifier. Biomass and Bioenergy. 35(10): 4215-4220.

[21] Erlich, Catharina, and Torsten H. Fransson. 2011. Downdraft Gasification of Pellets Made of Wood, Palm-oil Residues Respective Bagasse: Experimental Study. Applied Energy. 88(3): 899-908.

[22] Sharma, Avdhesh Kr. 2009. Experimental Study on 75 kWth Downdraft (biomass) Gasifier System. Renewable Energy. 34(7): 1726-1733.

[23] Samiran, Nor Afzanizam, Mohammad Nazri Mohd Jaafar, Jo-Han Ng, Su Shiung Lam, and Cheng Tung Chong. 2016. Progress in Biomass Gasification Technique-with Focus on Malaysian Palm Biomass for Syngas Production. Renewable and Sustainable Energy Reviews. 62: 1047-1062.

[24] Udomsirichakorn, Jakkapong, Prabir Basu, P. Abdul Salam, and Bishnu Acharya. 2013. Effect of $\mathrm{CaO}$ on Tar Reforming to Hydrogen-enriched Gas with In-Process CO2 Capture in a Bubbling Fluidized Bed Biomass Steam Gasifier. International Journal of Hydrogen Energy. 38(34): 1449514504.

[25] Arromdee, Porametr, and Vladimir I. Kuprianov. 2012. A Comparative Study on Combustion of Sunflower Shells in Bubbling and Swirling Fluidized-bed Combustors with a Cone-shaped Bed. Chemical Engineering and Processing: Process Intensification. 62: 26-38.

[26] Karatas, Hakan, Hayati Olgun, and Fehmi Akgun. 2013. Experimental Results of Gasification of Cotton Stalk and Hazelnut Shell in a Bubbling Fluidized Bed Gasifier under Air and Steam Atmospheres. Fuel. 112: 494-501.

[27] Alauddin, Zainal Alimuddin Bin Zainal, Pooya Lahijani, Maedeh Mohammadi, and Abdul Rahman Mohamed. 2010. Gasification of Lignocellulosic Biomass in Fluidized Beds for Renewable Energy Development: A Review. Renewable and Sustainable Energy Reviews. 14(9): 28522862.

[28] Mom, M., and Shaharin A. Sulaiman. 2013. Downdraft Gasification of Oil Palm Frond: Effects of Temperature and Operation Time. Asian J Sci Res. 6: 197.
[29] Ninduangdee, Pichet, and Vladimir I. Kuprianov. 2014. Combustion of Palm Kernel Shell in a Fluidized Bed: Optimization of Biomass Particle Size and Operating Conditions. Energy Conversion and Management. 85: 800808.

[30] Ganjehkaviri, Abdolsaeid, Mohammad Nazri Mohd Jaafar, Seyed Ehsan Hosseini, and Anas Basri Musthafa. 2016. Performance Evaluation of Palm Oil-based Biodiesel Combustion in an Oil Burner. Energies. 9(2): 97.

[31] Abdul Malik, Muhammad Syahiran, Ashrul Ishak Mohamad Shaiful, Mohd Shuisma Mohd Ismail, Mohammad Nazri Mohd Jaafar, and Amirah Mohamad Sahar. 2017. Combustion and Emission Characteristics of Coconut-Based Biodiesel in a Liquid Fuel Burner. Energies. 10(4): 458.

[32] Ja'afar, Mohammad Nazri Mohd, Wan Zaidi Wan Omar, Muhammad Roslan Rahim, Ismail Azmi, and Mohd Hisyam Abdullah. 2014. Study on Combustion Performance of Palm Oil Biodiesel Blend. J. Teknol. 69: 127-131.

[33] Shahbaz, M., S. Yusup, M. Y. Naz, S. A. Sulaiman, A. Inayat and A. Partama. 2017. Fluidization of Palm Kernel Shell, Palm Oil Fronds, and Empty Fruit Bunches in a Swirling Fluidized Bed Gasifier. Particulate Science and Technology. 35(2): 150-157.

[34] Samiran, Nor Afzanizam, Jo-Han Ng, Mohammad Nazri Mohd Jaafar, Agustin Valera-Medina, and Cheng Tung Chong. 2017. Swirl Stability and Emission Characteristics of CO-enriched Syngas/Air Flame in a Premixed Swirl Burner. Process Safety and Environmental Protection. 112:315-326.

[35] Ghenai, Chaouki. 2015. Combustion and Emissions Performance of Syngas Fuels Derived from Palm Kernel Shell and Polyethylene (PE) Waste via Catalytic Steam Gasification. Combustion. 1: 61291.

[36] Rahim, Muhammad Roslan, and Mohammad Nazri Mohd Jaafar. 2017. Kesan Sudut Pusaran Terhadap Pembentukan Emisi Menggunakan Dwl Pemusar Udara Aliran Jejarian. Jurnal Teknologi. 79(2): 137-146. 